works adjoining the Thames at Barn Elms and Barnes where there are, in addition to primary filters at Barn Elms, 5 and $19 t$ acres respectively of slow sand filters from which a total of 27-31 million gallons a day of filtered water is obtained. The top water level of these filter beds varies from $11 \mathrm{ft}$. to $16 \mathrm{ft}$. above Ordnance datum, while the bottoms of the filters lie between $4 \mathrm{ft}$. and $9 \mathrm{ft}$. below the same datum. Were the water in the Thames to be permanently impounded, as contemplated in the scheme, the level of the ground water would be raised to a height substantially above the floor level of the filter beds, and these would accordingly stand in a body of polluted water, a condition for which they were not designed, and would be beset with risks of contamination to the filtered water. Another danger would be the increased external pressure against the structures during the periods of evacuation for cleaning. The report went on to show that the reception into the river of sewage and storm water laden with sedimentary matter of a putrefactive and infective character within the limits of the impounded area, would induce in the summer season insanitary conditions, resulting in demands for the release of increasing volumes of water over Teddington Weir in order to abate the nuisance, and that this would jeopardize the integrity of the Metropolitan supply at a time of high water consumption. The report concluded with a strong recommendation to offer strenuous opposition to the scheme.

\section{Galloway Hydro-electric Power Development}

AT the Institution of Civil Engineers on February 22, a series of papers was read dealing with the inception and execution of the undertaking belonging to the Galloway Water Power Co., situated in the south-west of Scotland and occupying the southerm portion of the mountainous region which lies between the estuaries of the Clyde and the Solway. The first paper by W. Hudson and J. K. Hunter gave an account of the initiatory stages and constructional details of the work. The area which has been developed includes the entire catchment (345 square miles) of the Galloway Dee, with, in addition, a further 50 square miles to the north-west, forming the catchment area of Loch Doon. With a slight exception, all the works lie on the greywacke formation, having a soft and shaly consistency. The climate is mild and the rainfall comparatively heavy, varying from 40 inches per annum on the coast to the south to more than 90 inches on the high ground between Loch Trool and Loch Doon. The more important works in their natural sequence consist of the Loch Doon storage reservoir, which provides main seasonal storage for the upper three power stations on the Dee, having an available capacity of 2,930 million $\mathrm{cu}$. $\mathrm{ft}$. and a total draw-down of $40 \mathrm{ft}$. The original level of the loch has been raised by $27 \mathrm{ft}$. Then come the Doon-Deugh tunnels by which water is drawn from the reservoir and discharged, as required, into the Dee. A series of three power stations have been installed at Kendoon, Carsfad and Earlstoun, normally operated together. A fourth station at
Glenlee with a reservoir at Clatteringshaws Loch, and a fifth station at Tongland complete the chain of development. The paper by $W$. Hawthorne and F. H. Williams described the mechanical and electrical plant, consisting of eleven main generating sets with outputs of $6,000-12,000$ kilowatts, the total rated capacity being 102,000 kilowatts and the voltage 11,000. The third paper, by $H$. W. Mountain, co-related the scheme with reference to the Grid, by which the bulk of the output is exported, half to central Scotland and half to north-west England. The total expenditure on the Galloway Development amounted approximately to $£ 3,000,000$ and the work was completed in the autumn of 1936 .

\section{Planning in a Democratic Government}

IN an article, "The Place of 'Planning' in a Demo. cratic Government", in the Nineteenth Century of December, Sir Daniel Hall discusses some of the reasons for the apparent inefficiency of democratic Government as compared with the efficiency of totalitarian States, and particularly with reference to the position of the technical expert in democratic administration. The problem of parliamentary Government, he suggests, is that of introducing planning into its administrative machinery to an extent which will permit a degree of foresight in the conduct of public affairs that will take long views, anticipate the effect of material progress on the social organism and concern itself with matters affecting the national welfare which have but little popular appeal. Sir Daniel Hall points out that the conception of planning has already entered our system to some extent, but our schemes are usually piecemeal and without provision for the consideration of their place in the national economy as a whole, while technical opinion is liable to be over-ruled and decisions determined less on intrinsic merits and informed criticism of proposals than by the volume of opposition aroused.

Sir Daniel Hall considers that it is on this question of expert advice and authority that the British administrative system is weakest, although in recent years successive Governments have come to recognize the need for technical advice and established such bodies as the Development Commission, the Department of Scientific and Industrial Research and the Medical Research Council. These bodies and par. ticularly the Economic Advisory Council provide the nucleus of an organization which could exercise the function of planning within the ordinary machinery of Government, and Sir Daniel Hall suggests that the Economic Advisory Council should be replaced by a Planning Council with a strengthened personnel and a technical staff, linked with the Research Councils. The Planning Council would remain an advisory body with the immediate function of advising the Cabinet or the departments on any question submitted to it. Its most important function, however, would be its initiative in planning, and its constitution would afford men eminent in the industrial, commercial, financial and scientific world opportunity of putting 